Canadian Journal of Higher Education

Revue canadienne d'enseignement supérieur

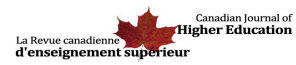

\title{
Predictors of Student Success in Canadian Polytechnics and CEGEPS
}

\author{
Heather L. Ramey, Heather L. Lawford, Heather Chalmers et Yana Lakman
}

Volume 48, numéro 2, 2018

URI : https://id.erudit.org/iderudit/1057104ar

DOI : https://doi.org/10.7202/1057104ar

Aller au sommaire du numéro

\section{Éditeur(s)}

Canadian Society for the Study of Higher Education

ISSN

2293-6602 (numérique)

Découvrir la revue

Citer cet article

Ramey, H., Lawford, H., Chalmers, H. \& Lakman, Y. (2018). Predictors of Student Success in Canadian Polytechnics and CEGEPs. Canadian Journal of Higher Education / Revue canadienne d'enseignement supérieur, 48(2), 74-91. https://doi.org/10.7202/1057104ar

\section{Résumé de l'article}

La réussite étudiante dans les institutions d'éducation post-secondaire est une source de préoccupation constant. Toutefois, les études publiées jusqu'à présent portaient sur des échantillons universitaires relativement homogènes. De plus, les recherches canadiennes portant sur les indicateurs prévisionnels de la réussite étudiante sont limitées. Emboîtant le pas à de nouvelles tendances, nous avons étudié les qualités personnelles non-cognitives, plutôt que les indicateurs prévisionnels cognitifs (ex. QI) de la réussite étudiante. Suivant un modèle psycho-social, nous nous sommes penchés sur l'âge, le sexe, le niveau perçu de stress, l'éducation maternelle, le style identitaire, la persévérance, et l'engagement des étudiants à titre d'indicateurs prévisionnels de réussite étudiante chez un échantillon multi-sites d'étudiants qui fréquentent un CÉGEP au Québec ( $\mathrm{N}=239$; Mage = 18.6 ans; $68.2 \%$ femmes $)$ ainsi qu'une école polytechnique ontarienne ( $\mathrm{N}=209$; Mage = 20.6 ans; $71.3 \%$ femmes). L'éducation maternelle et la persévérance se sont révélées des indicateurs importants pour les deux échantillons. Le lien entre l'identité informationnelle, l'engagement cognitif, et la réussite étudiante variaient selon les lieux. Nos résultats démontrent qu'il faut davantage porter l'attention sur la persévérance étudiante, et de voir l'identité et l'engagement cognitifs à titre de facteurs qui dépendent du contexte éducationnel.
Copyright (c) Heather L. Ramey, Heather L. Lawford, Heather Chalmers, Yana Lakman, 2018
Ce document est protégé par la loi sur le droit d'auteur. L’utilisation des services d'Érudit (y compris la reproduction) est assujettie à sa politique d'utilisation que vous pouvez consulter en ligne.

https://apropos.erudit.org/fr/usagers/politique-dutilisation/ 


\title{
Predictors of Student Success in Canadian Polytechnics and CEGEPs
}

\author{
Heather Ramey \\ Humber Institute of Technology and Advanced Learning \\ Heather Lawford \\ Bishop's University \\ Heather Chalmers \\ Brock University \\ Yana Lakman \\ Brock University
}

\begin{abstract}
Student success in post-secondary education is an ongoing concern, however, research has focused on relatively homogeneous university samples. Moreover, Canadian research on predictors of student success is limited. Following recent trends, we examined non-cognitive, personal qualities, rather than cognitive predictors (e.g., IQ), of student success. Relying on a psychosocial model, we examined age, gender, perceived stress, maternal education, identity style, perseverance, and student engagement as predictors of student success in a multi-site sample of students attending a CEGEP in Quebec $\left(N=239 ; M_{\text {age }}\right.$ $=18.6$ years; $68.2 \%$ female $)$ and a polytechnic school in Ontario $\left(N=209 ; M_{\text {age }}\right.$ $=20.6$ years; $71.3 \%$ female). Maternal education and perseverance emerged as significant predictors in both samples. Links between informational identity and cognitive engagement and student success differed by location. Our findings suggest the need to focus on student perseverance, and to consider identity and cognitive engagement dependent on the educational context.
\end{abstract}




\section{Résumé}

La réussite étudiante dans les institutions d'éducation post-secondaire est une source de préoccupation constant. Toutefois, les études publiées jusqu'à présent portaient sur des échantillons universitaires relativement homogènes. De plus, les recherches canadiennes portant sur les indicateurs prévisionnels de la réussite étudiante sont limitées. Emboîtant le pas à de nouvelles tendances, nous avons étudié les qualités personnelles noncognitives, plutôt que les indicateurs prévisionnels cognitifs (ex. QI) de la réussite étudiante. Suivant un modèle psycho-social, nous nous sommes penchés sur l'âge, le sexe, le niveau perçu de stress, l'éducation maternelle, le style identitaire, la persévérance, et l'engagement des étudiants à titre d'indicateurs prévisionnels de réussite étudiante chez un échantillon multisites d'étudiants qui fréquentent un CÉGEP au Québec $\left(N=239 ; M_{\text {age }}=18.6\right.$ ans; $68.2 \%$ femmes $)$ ainsi qu'une école polytechnique ontarienne $(N=209$; $M_{\text {age }}=20.6$ ans; $71.3 \%$ femmes). L'éducation maternelle et la persévérance se sont révélées des indicateurs importants pour les deux échantillons. Le lien entrel'identitéinformationnelle, l'engagement cognitif, et la réussite étudiante variaient selon les lieux. Nos résultats démontrent qu'il faut davantage porter l'attention sur la persévérance étudiante, et de voir l'identité et l'engagement cognitifs à titre de facteurs qui dépendent du contexte éducationnel.

\section{Predictors of Student Success in Non-University Post-Secondary Contexts}

Student success in post-secondary education is an ongoing concern, likely because of numerous factors, including Canadian government funding models focused on student success and attrition (Childs, Finnie, \& Martinello, 2017; Ministry of Training, Colleges and Universities, 2015). A wave of recent Canadian research on post-secondary attendance has emerged from the Youth in Transitions Survey, focusing on factors that predict attendance and persistence (Childs et al., 2017; Jerrim \& Vignoles, 2015), but Canadian research on predictors of student success (i.e., average grades) appears to be more limited. Disproportionately, existing research on student success in post-secondary contexts has focused on relatively homogeneous samples of undergraduate university students, particularly those in psychology programs (Henrich, Heine, \& Norenzayan, 2010; O'Connell \& Sheikh, 2011; Vedel, 2014), creating a need to explore associations in other post-secondary student populations. In college and university samples, there is evidence that a range of demographic (e.g., gender, age) and, increasingly, psychosocial factors (e.g., engagement, effort) predict student success (Dooley, Payne, \& Robb, 2012; Fong, Davis, Kim, Kim, Marriott, \& Kim, 2017; Richardson, Abraham, \& Bond, 2012). In the current study, we examine predictors of student success, including age, gender, maternal education, stress, informational identity style, perseverance, and cognitive engagement, in two non-university samples of post-secondary students attending a junior college (CEGEP) in Quebec and a polytechnic institution in Ontario. 


\section{Post-Secondary Context}

In Canada, of the two million students attending post-secondary institutions, approximately 750,000 attend college (Statistics Canada, 2016), a number which includes at least 190,000 students attending a polytechnic (Polytechnics Canada, 2015). In Canada, polytechnics provide a range of education credentials, including diplomas and degrees, and are intended to combine the practical training characteristic of college education with the depth of study characteristic of university degrees (Polytechnics Canada, 2016).

Quebec's post-secondary system is unique when compared with the rest of Canada. Recent statistics indicate that approximately 175,000 students are attending a CEGEP in Quebec (Les cégeps du Québec, 2016). CEGEPs are forms of publicly funded junior colleges that are found only in Quebec (Les cégeps du Québec, 2016). In comparison with other post-secondary systems in Canada, CEGEPs offers multiple functions that depend on the student and the stream ultimately chosen. They can serve as an optional final year of high school, and also award terminal college or technical diplomas. If a student wants to continue on to university, the student is required to attend CEGEP first and attendance is mandatory. For these students, CEGEP serves as the first stage (typically the first year) of university education (Fédération des cégeps, 2016; Les cégeps du Québec, 2016).

Research on students who attend CEGEPs and polytechnics appears to be rare or, at best, combines data from students in the broader college population (Childs et al., 2017; Childs, Finnie, \& Mueller, 2018), leaving the experiences of these students relatively unexamined in comparison to university samples in Canada. The applicability of current models of student success to CEGEP and polytechnic populations is therefore unclear.

\section{Predictors of Student Success}

Student success in post-secondary settings has typically been measured using average grades (Lounsbury, Fisher, Levy, \& Welsh, 2009; Richardson et al., 2012). In Canadian research, student success, as measured by grades in the first year of post-secondary education, has been related to student attrition (Ma \& Frempong, 2013) and to graduate employment (Richardson et al., 2012).

Recently, researchers have argued for the need to examine psychosocial factors (Fong et al., 2017) or "personal qualities" in predicting student success (Duckworth \& Yeager, 2015, p. 239). Duckworth and Yeager have argued that personal qualities are more malleable and subject to intervention than the cognitive factors (e.g., IQ) that have been the focus of extensive research on academic success in the past. Personal qualities include dispositional (e.g., identity, perseverance) as well as more contextually specific predictors (e.g., engagement) of student success (Duckworth \& Yeager, 2015, p. 239).

Identity processing style, which postulates that people rely on different socio-cognitive processing styles in constructing their identities, has been related to post-secondary student success (e.g., Berzonsky \& Kuk, 2005). An informational identity style, in which youth actively seek out and process information relevant to the self (Berzonsky et al., 2013), may be ideal. Other processing styles include normative identity-processing, in which youth conform to the expectations of parents and others and expend little mental effort exploring alternatives, and a diffuse-avoiding identity-processing style, in which youth attempt to delay identity-relevant decisions (Berzonsky, 2011). Post-secondary 
students with an informational identity style, in contrast, tend to have greater academic self-sufficiency and more effective life-management skills than students relying on other identity styles (Berzonsky \& Kuk, 2005). Relevant to the current study, Seabi and Payne (2013) have suggested that context, including differences in educational preparation, might play a role in how identity style predicts grades.

Similar to informational identity style, perseverance is a dispositional psychosocial factor that reflects an individual's active, constructive approach toward information or learning (Peterson \& Seligman, 2004). Perseverance represents continuing despite obstacles, staying on task, and completing tasks that have been undertaken (Peterson \& Seligman, 2004). In studies involving undergraduate psychology students, perseverance has been found to positively predict college student success (Lounsbury et al., 2009; Saldaña et al., 2014). Perseverance corresponds to conscientiousness from the five-factor model of personality (Peterson \& Seligman, 2004). Past research (McAbee \& Oswald, 2013; Vedel, 2014) has pointed to conscientiousness as the strongest personality trait in predicting student success, across a number of personality measures. Some researchers have argued that it is the best predictor of student success (Brown, Brown, Beale, \& Gould, 2014), and it appears to predict student success largely independent of intelligence (Poropat, 2009). One advantage to the examination of perseverance as a character strength, rather than conscientiousness, is that character strengths are narrower and able to capture more nuanced individual differences than broader personality constructs (Peterson \& Seligman, 2004). Peterson and Seligman (2004) have described character strengths as traits that are relatively stable, yet can also be shaped by context and are capable of change. Further, a current body of research on interventions, with regard to character strengths, supports the argument that character strengths are changeable and subject to intervention (Niemiec, 2013).

In addition to dispositional factors, students' engagement in the learning context is a further psychosocial factor that might be a more specific demonstration of an individual's interaction with their school context. Student engagement is a multidimensional construct, frequently considered to include behavioural, emotional, and cognitive components (Fredricks \& McColskey, 2012), and typically refers to students' psychological investment or effort in learning or mastering knowledge or skills (Newmann, Wehlage, \& Lamborn, 1992). It is considered both essential for learning and modifiable through school practices and policies (Finn \& Zimmer, 2012). Post-secondary student engagement has been related to student success in both university and college students (e.g., Fredricks \& McColskey, 2012; Hassaskhah, Khanzadeh, \& Zade, 2012). Particularly, cognitive engagement, defined as students' investment in learning (Fredricks \& McColskey, 2012), has been found to be related to student success (Hassaskhah et al., 2012). More specifically, given the relatively voluntary nature of post-secondary education, students' beliefs regarding the value of school, as it relates to their learning goals and future aspirations, is an element of cognitive engagement that been related to academic resilience (Strolin-Goltzmam, Woodhouse, Suter, \& Werrbach, 2016), and might be an important predictor of student success.

Given the prominent position of negative emotions in post-secondary education (Fong et al., 2017), it is important to consider stress within potential psychosocial models of student success. Separate from dispositional and motivational factors (Fong et al., 2017), 
stress might have deleterious effects, impeding student engagement, learning, and success (Akgun \& Ciarrochi, 2003; Struthers, Perry, \& Menec, 2000). It is expected that students transitioning into new post-secondary contexts would experience some levels of stress, which might affect their academic performance. For example, Shah, Hasan, Malik, and Sreeramareddy (2010) found that undergraduate students in medical schools reported stress from higher expectations from parents, greater number of exams, fuller schedules and curriculum, worsened sleep, other worries, and feelings of loneliness. Akgun and Ciarrochi (2003) reported that students who demonstrated low resourcefulness (i.e., behavioural and cognitive skills that aid in regulation) had experienced more adverse effects from stress, specifically with respect to their grades. However, these findings contradict other studies that found no statistically significant association between perceived stress and student success (Shah et al., 2010). Similarly, in a study that examined factors associated with school-related success, Frischenschlager, Haidinger, and Mitterauer (2005) noted that although students who were academically strong reported less stressful experiences, perceived stress was not a factor that predicted whether these students succeeded academically. In a recent meta-analysis of predictors of success in university students, Richardson, Abraham, and Bond (2012) found that anxiety and perceived stress were negatively associated with post-secondary success; however, a similar meta-analysis focused on community college students (Fong et al., 2017) found no significant relations. In sum, since stress is a potential, though not consistently confirmed, predictor of student success, it is important to consider in current research.

Beyond psychosocial and non-cognitive factors in predicting student success, researchers have typically examined demographic and background factors, including gender, age, and maternal education. In their meta-analysis of predictors of student success, Richardson et al. (2012) report that past research on age is mixed, but that, with regard to gender, female students typically attain higher grade point averages (GPAs) than male students. Past research on maternal education is complex and has tended to use parental education and income to represent socio-economic factors (Childs et al., 2018; Finnie, Wismer, \& Mueller, 2015). However, recent Canadian research by Childs, Finnie, and colleagues (Childs et al., 2018; Finnie et al., 2015) found that parental education was a significant predictor of post-secondary education, over and above family income, particularly for university attendance. Thus, due to these mixed findings and limited Canadian research, the current study included age, gender, and maternal education as potential predictors.

\section{The Current Study}

The purpose of this study was to extend past research on predictors of student success in post-secondary education by examining potential psychosocial factors in post-secondary contexts outside of traditional university settings. Specifically, our research question was "How do demographic (e.g., age, gender, maternal education) and psychosocial (e.g., informational identity style, perseverance, cognitive engagement, and stress) factors predict student success in two non-university samples of Canadian post-secondary students?" Further, we tested the applicability of this model across the two post-secondary contexts, a CEGEP (junior college) in Quebec and a polytechnic in Ontario, to examine the consistency of our model across groups. 


\section{Method}

\section{Participants and Procedure}

We used two distinct samples in the current study. Both were recruited as part of a longitudinal study of transitions in emerging adulthood and positive development. Ethical approval was granted by the Research Ethics Boards at both Humber and Bishop's University. Participants in Sample 1 were first-year students attending a CEGEP in Quebec $(N=239$; Mean age $=18.6$ years; $S D=1.3$ years; age range $17-24 ; 68.2 \%$ female $)$. Students were recruited through visits to a common area on the campus, where they were invited to complete paper copies of surveys. Participants most frequently identified as White (81\%), Black (3\%), Asian (4\%), and of mixed origin (5\%). The remaining $7 \%$ of participants endorsed one of a number of other ethnic/racial categories (e.g., African, Indigenous Peoples, "other"), each of which were endorsed by fewer than $3 \%$ of the sample. Overall, the most common grade average (for $42 \%$ of participants) was between $80 \%$ and $89 \%$. Reports of maternal education were diverse; participants most commonly reported maternal education as having completed some university or college (33\%), and least commonly as some high school (7\%).

Participants in Sample 2 were first-year polytechnic students in social and community services programs in Ontario $(N=209$; Mean age $=20.6$ years; $S D=2.2$ years; age range 17-31; 71.3\% female). Participants were current students in the Child and Youth Care diploma (17.1\%) or degree (11.7\%) programs, or the Community and Justice Services (33.2\%) or Criminal Justice degree (38.0\%) programs. Students were recruited through visits to first-year classes. They were invited to complete paper copies of surveys. Participants identified as White (42\%), Black (22\%), Asian (18\%), and of mixed origin (6\%). The remaining $12 \%$ of participants endorsed one of a number of other ethnic/racial categories, each of which were endorsed by fewer than $3 \%$ of the sample. Overall, the most common grade average (for $42 \%$ of participants) was between $70 \%$ and $79 \%$. Reports of maternal education were again diverse; participants most commonly reported maternal education as having completed university or college (30\%), and least commonly as having completed a professional degree or graduate school (8\%).

There were some demographic differences between the two samples. As CEGEP might be considered a form of junior college and might begin a year earlier than the polytechnic and other post-secondary institutions outside of Quebec, it is not surprising that the undergraduate sample was significantly older than the CEGEP sample, $t(418)=-11.13, p<$ .001. There was no significant difference in gender or level of maternal education.

\section{Measures}

Means, standard deviations, and correlations are presented in Table 1. 
Polytechnic and CEGEP Student Success / H. Ramey, H. Lawford, H. Chalmers, \& Y. Lakman 80

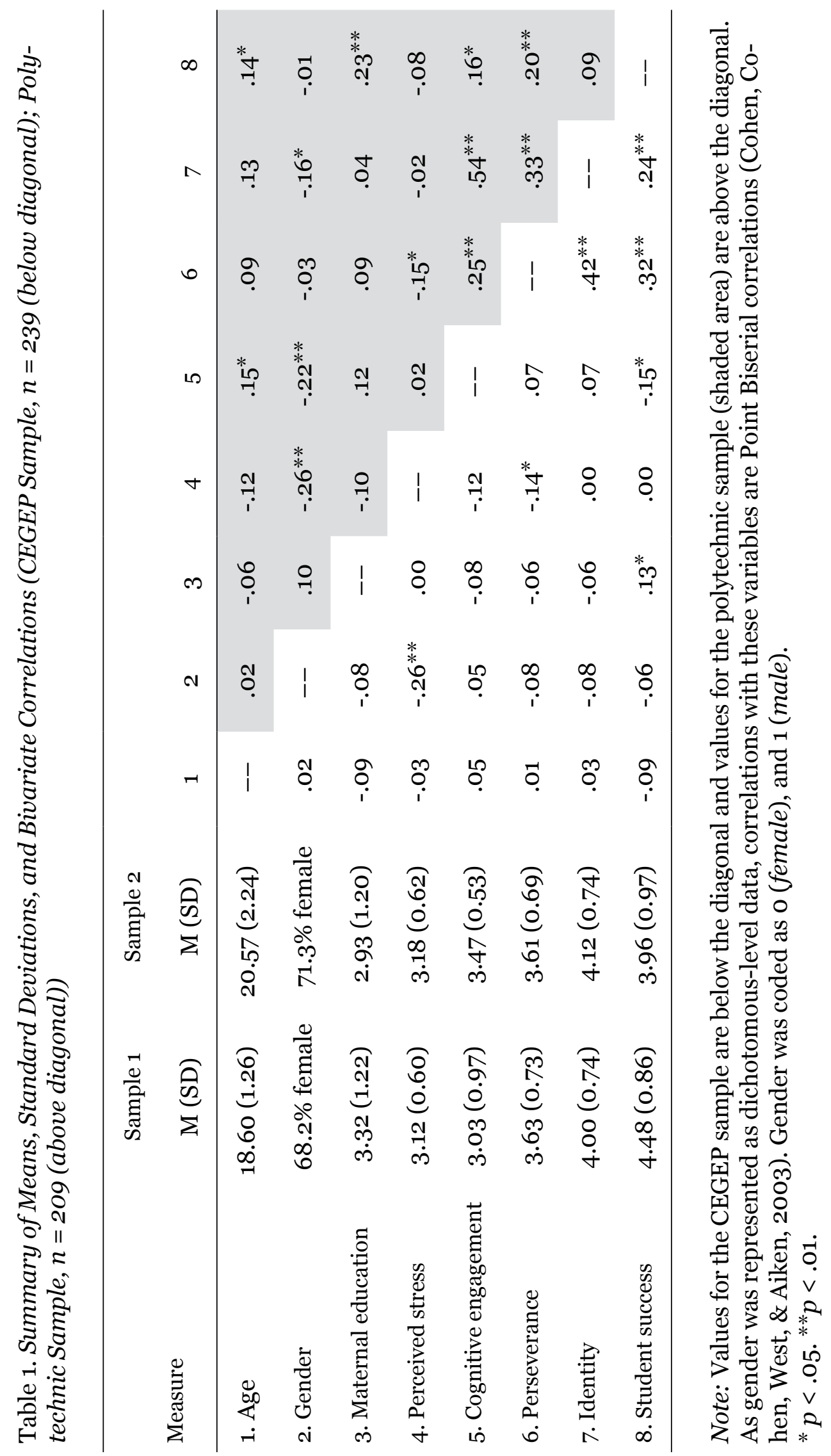


Demographics. Participant age, gender, ethnicity, and maternal education were measured with single items. Responses on the maternal education item could range from 1 (some high school) to 5 (professional degree or graduate school).

Perceived Stress. Perceived stress was measured with the Perceived Stress Scale (Cohen, Kamarck, \& Mermelstein, 1983; 10 items, averaged, e.g., "In the last month, how often have you felt nervous and stressed?" CEGEP sample, $\alpha=.79$, polytechnic sample, $\alpha$ $=.81$ ). Responses could range from 1 (never) to 5 (very often).

Cognitive Engagement. Cognitive engagement, in the form of students' beliefs about the value of their education for their learning goals and future aspirations, was measured with the Future Aspirations and Goals subscale of the Student Engagement Instrument (Appleton, Christenson, Kim, \& Reschly, 2006; Grier-Reed, Appleton, Rodriguez, Ganuza, \& Reschly, 2012; 5 items, averaged, e.g., "School is important for achieving my future goals," CEGEP sample, $\alpha=.96$, polytechnic sample, $\alpha=.86$ ). Responses could range from 1 (strongly disagree) to 4 (strongly agree).

Identity Style. Identity style was measured with the information-oriented subscale of the Identity Style Inventory (ISI-4; Berzonsky et al., 2013; Smits, Berzonsky, Soenens, Luyckx, Goossens, Kunnen, \& Bosma, 2008; 7 items, averaged; e.g., "When making important life decisions, I like to have as much information as possible," CEGEP sample, $\alpha$ $=.88$, polytechnic sample, $\alpha=.89$ ). Responses could range from 1 (not at all like me) to 5 (very much like me).

Perseverance. Perseverance was assessed with the Industry/Perseverance/Persistence scale from the VIA-Youth (Park \& Peterson, 2006; see also McGrath \& Walker, 2016; Ruch, Weber, Park, \& Peterson, 2014; 8 items, averaged, e.g., "People can count on me to get things done," CEGEP sample, $\alpha=.83$, polytechnic sample, $\alpha=.80$ ). Responses could range from 1 (not at all like me) to 5 (very much like me).

Student Success. Student success was measured with a single item asking participants' average grades over the past term (Baldwin, Bensimon, Dowd, \& Kleiman, 2011). Responses on the average grades item could range from 1 (below 50\%) to 6 (90-100\%).

\section{Missing Data and Plan of Analysis}

Some participants did not complete all survey questions: 2.6\% (Sample 1) and 1.1\% (Sample 2) of the data were missing. Missing values were imputed using the EM algorithm in SPSS (Schafer \& Graham, 2002).

Following an examination of descriptive statistics and bivariate correlations, the models were tested with structural equation modeling (SEM) on the combined sample, using the Amos software program. Although our test was of a path model, and no latent variables were included, we chose to use SEM rather than regression for a more robust test. Following the main analyses, we conducted multigroup analysis to test the strength of the paths in the two different samples. SEM provides the option of multigroup analysis, which is used to indicate whether a model fits equivalently across two or more groups (Kline, 2011). 


\section{Results}

First, we conducted an examination of means and bivariate correlations (see Table 1). On average, stress, identity, cognitive engagement, and perseverance all had means above their scale midpoint. Age was correlated with greater cognitive engagement in the polytechnic sample only, and was not significantly related to any other variables. Gender was correlated with perceived stress in both samples, such that female participants tended to report greater stress, in both samples. In the polytechnic sample only, female participants also tended to report higher cognitive engagement. Moreover, maternal education was correlated with greater student success, but with no other variables, in both samples. Stress was negatively correlated with perseverance in both samples. Perseverance also was positively related to identity in both samples, and both perseverance and identity were positively related to cognitive engagement in the polytechnic sample only. In both samples, student success was positively and significantly related to maternal education and to perseverance, and was also significantly related to cognitive engagement in both samples, although this association was positive in the polytechnic sample and negative in the CEGEP sample. Student success was positively correlated with age in the polytechnic sample but not in the CEGEP sample. Gender was not correlated with student success in either sample, and was thus excluded from further analysis. Stress was also not significantly related to student success in either sample. We also examined potential curvilinear associations between stress and student success, through a hierarchical regression analysis, in case a moderate amount of stress was related to student success but too much or too little stress negatively impacted grades. We entered control variables in the first step (i.e., sample, age, maternal education), main predictors in the second (i.e., perceived stress, cognitive engagement, identity style, and perseverance), and a curvilinear quadratic term for perceived stress in the third step. The addition of the quadratic term in the third step was non-significant $(p=.48)$. Given the non-significant associations, stress was also excluded from further analysis.

In the main analysis (see Table 2), grades was regressed onto all hypothesized predictors and control variables, and non-significant paths were eliminated from the model. Because maternal education, age, and the main predictors of cognitive engagement, identity, and perseverance were all correlated with student success, we entered all into the model simultaneously to predict student success. The model was saturated. Maternal education, cognitive engagement, and perseverance all significantly predicted student success $(p<$ $.001, p=.003, p<.001$, respectively). Age was not a significant predictor $(p=.341)$, and identity style approached significance $(p=.076)$.

To test whether paths from predictors to student success were consistent across samples, we conducted a multiple-group SEM (see Table 2; Kline, 2011). Following Gaskin's (2016) interaction analysis, we calculated $z$-scores to test for the equality of paths predicting student success across samples. There were no significant differences for perseverance or maternal education $(z=-0.991, p=.321, z=1.146, p=.252$, respectively). The paths from cognitive engagement to student success significantly differed between the two samples $(z=2.020, p=.043)$. Cognitive engagement significantly and negatively predicted student success in the CEGEP sample $(\mathrm{b}=-.147, p=.005)$, but was not a significant predictor in the polytechnic sample $(b=.160, p=.262)$. Differences in paths from identity 
style and age to student success approached significance $(z=-1.668, p=.095 ; z=1.734$, $p=.083$, respectively). Identity style significantly and positively predicted student success in the CEGEP sample $(\mathrm{b}=.164, p=.032)$, but was not a significant predictor in the polytechnic sample $(\mathrm{b}=-.052, p=.619)$. Age was not significant in the CEGEP sample $(\mathrm{b}$ $=-.027, p=.492$ ), but was a significant and positive predictor in the polytechnic sample $(\mathrm{b}=.058, p=0.044)$.

Table 2. Parameter Estimates for Structural Equation Model of Maternal Education, Age, Identity, Cognitive Engagement, and Perseverance Predicting Student Success (Both Samples Combined)

\begin{tabular}{lcc}
\hline Parameter & $\begin{array}{c}\text { Standardized Path } \\
\text { Coefficient }\end{array}$ & $\begin{array}{c}\text { Unstandardized Path } \\
\text { Coefficient (SE) }\end{array}$ \\
\hline Age & -.020 & $4.169(0.279)$ \\
Maternal education & $.156^{* *}$ & $1.464(0.098)$ \\
Identity & .111 & $0.543(0.036)$ \\
$\begin{array}{l}\text { Cognitive engagement (Future goals and } \\
\text { aspirations) } \\
\text { Perseverance }\end{array}$ & $-.159^{* *}$ & $0.676(0.045)$ \\
\hline
\end{tabular}

${ }^{*} p<.05 .{ }^{* *} p<.01$.

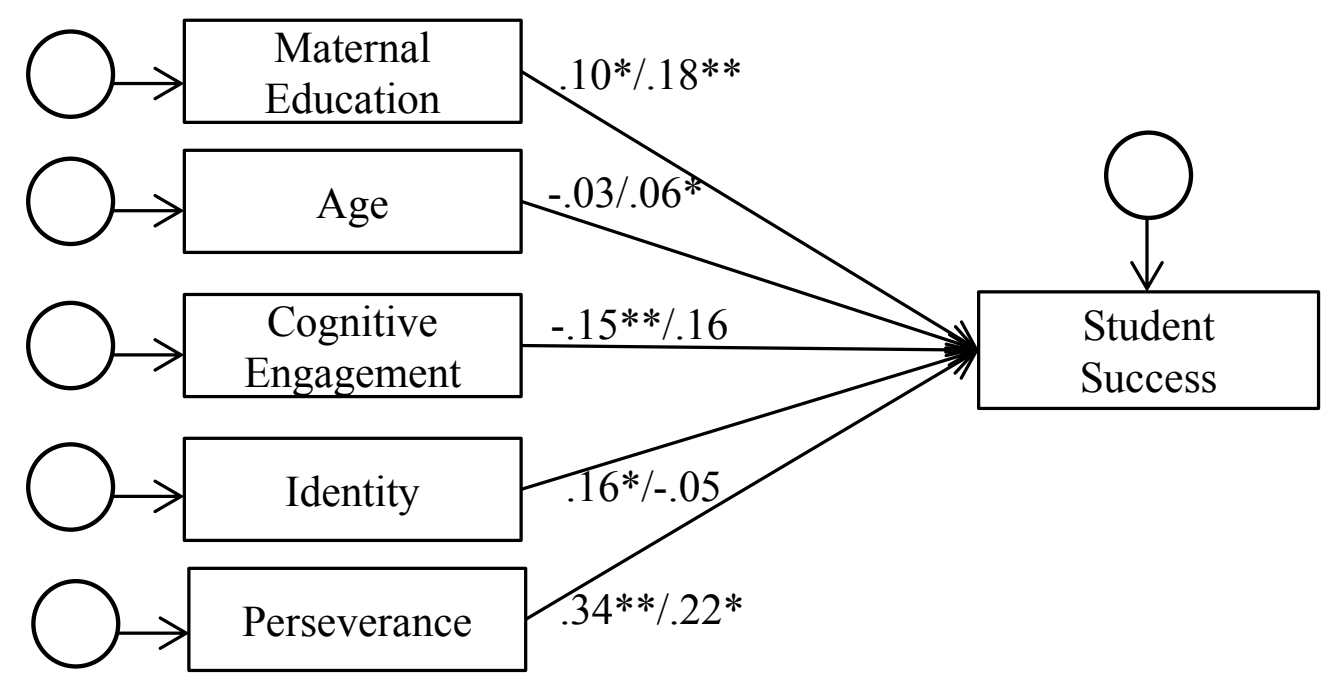

Figure 1. Structural Equation Model predicting student success for CEGEP/polytechnic samples.

Standardized estimates are for CEGEP/polytechnic samples.

${ }^{*} p \leq .05 .{ }^{* *} p \leq .01$. 


\section{Discussion}

In the current study, we explored demographic and psychosocial predictors of student success in two distinct, relatively untapped post-secondary samples. We found that among our range of predictors, only maternal education and perseverance emerged as significant in both samples. Perceived stress did not emerge as important to student success in either sample. Cognitive engagement and identity style were related to student success in the CEGEP (junior college) sample but not in the polytechnic sample. Below, we discuss each of these findings in turn.

Consistent with past research on psychosocial predictors of student success (e.g., Fong et al., 2017), perseverance was a significant predictor in both samples. Students who demonstrated more initiative, were more persistent in their studies, and evinced continued effort in reaching goals were more successful. Our findings add to past research in suggesting that perseverance is a robust predictor, apparently relevant across a diversity of student populations.

Maternal education predicted academic success (i.e., average grades) in our samples. This is consistent with past research linking socio-economic status to student success in university (Richardson et al., 2012). It is also complements a recent body of Canadian research by Childs, Finnie, and colleagues (Childs et al., 2018; Finnie et al., 2015), on the predictive value of maternal education for students' post-secondary attendance. That research, however, focused on attendance, and did not differentiate polytechnic and CEGEP samples. Our findings further add to the work of Childs et al. (2018) and Finnie, Wismer, and Mueller (2015) by indicating the value of maternal education for student success, specifically, in our polytechnic and CEGEP samples.

Perceived stress was not a significant predictor of success in either sample, even at the bivariate level. Although consistent with previous research with college students in Canada (Fong et al., 2017), it appears to be inconsistent with students' own beliefs about what supports their success (Stelnicki, Nordstokke, \& Saklofske, 2015). Several recent studies suggest that the role of stress in students' lives is complex. Fong et al. (2017) noted that academic stress might serve as a threat appraisal, or a challenge appraisal, and thus might elicit positive (e.g., greater preparation) or negative (e.g., procrastination) coping behaviours. Barker, Galambos, Howard, and Wrosch (2016) recently found that a specific combination of negative and positive affect over time was related to academic success. Recent findings from a study of Canadian university students (Durand-Bush, McNeill, Harding, \& Dobransky, 2015) suggest that students are able to function and maintain well-being despite relatively high levels of stress, because self-regulation capacity provides a buffering effect. Given that, in the current study, stress was negatively related to perseverance but not to student success, our findings lend support to their argument. Thus, although not related to academic success in a straightforward way, stress might operate in interaction with other factors. Durand-Bush, McNeill, Harding, and Dobransky's (2015) findings, combined with the significant and positive bivariate correlation between stress and perseverance in the current study, further suggests that strengthening perseverance might ameliorate stress, in addition to potentially fostering student success.

Gender was not a significant predictor of student success, and age was significant only in the polytechnic sample. The finding regarding age is consistent with past research, 
which also has been mixed (Richardson et al., 2012). The CEGEP sample had a relatively narrow age range in contrast with the wider range in the polytechnic sample. Polytechnics' intended advantage of moving graduates rapidly into employment opportunities (Polytechnics Canada, 2015) might fit well for older students. In the current study, age differences were significant, with older students demonstrating greater academic success. It was unexpected that gender was not significant in the current study. In their study of Canadian university students, Dooley, Payne, and Robb (2012) found that female students had higher grades than male students, although they noted that these differences were numerically small. Future research is needed to explore whether there are gender differences in student success across other Canadian CEGEP and polytechnic student populations.

Informational identity style, indicating actively seeking out relevant information regarding options, was a significant predictor of student success in the CEGEP sample, but not in the polytechnic sample. This might be interpreted as lending support to Seabi and Payne's (2013) suggestion that context, including differences in educational preparation and maturity, might play a role in how identity style predicts grades. In the polytechnic sample, participants have already made some commitment with regard to work and education, particularly as polytechnics are applied settings, focused on specific careers. CEGEP, in contrast, serves as a stepping stone for students to select their next step, and thus, identity work might be important in settings where exploration is still encouraged. As the current report relies on a single CEGEP and a single polytechnic, further research is required to explore these possibilities.

The role of cognitive engagement also differed between the two samples. Students who were more cognitively engaged, believing that their schooling was important for their learning goals and future aspirations, tended to have lower student success in the CEGEP sample. This finding might reflect the different types of students and student paths in CEGEP education. Differentiating cognitive engagement according the many types of streams and paths available to CEGEP students was outside of the scope of the current project, but this finding may suggest the usefulness of exploring associations in non-university samples. In the polytechnic sample, cognitive engagement was not a significant predictor of student success. However, the significant and positive bivariate correlation indicates that the predictive power of cognitive engagement might be affected by shared variance with other predictors in the current model, including identity $(r=.54)$. Future goals and aspirations is only one element of cognitive engagement (Fredricks \& McColskey, 2012; Grier-Reed et al., 2012), with other aspects of cognitive engagement possibly serving as better measures of students' investment in learning in non-university samples, and thus as potential areas for intervention and support regarding student success.

\section{Limitations and Directions for Future Research}

The current study had a number of limitations, indicating future research directions. First, average grades over the past term were self-reported. Although reliable findings emerged, it is possible that some participants confused their GPA for the term with other forms of GPA (e.g., cumulative GPA). Although we attempted to gain official institutional data, they were unavailable due to limited resources at the institutional level. Future research, however, would benefit from the use of official GPA, to correct for possible errors in self-reporting. 
A further limitation is that the cross-sectional nature of our data precludes any conclusions regarding directionality. Although it is possible that greater perseverance and more positive identity development promotes student success, for example, it is also possible that earlier student success promotes the development of positive identity and student perseverance. It is also likely that additional variables, such as the likelihood of being awarded student scholarships, play a role. In sum, we suspect that these associations are more complex, and likely mutually reinforcing; however, future longitudinal research is needed.

In addition to a lack of ability to determine directionality, the current study was limited because it included only one polytechnic institute and one CEGEP. These institutions likely differ from others in a number of ways, including academic expectations, other demands, and peer influences. In the polytechnic sample, although students were from four different programs and two different credentials (diploma/degree), all of these programs were within the domain of social and community services, also limiting the potential generalizability of the current findings.

That stress was related to other variables, but not to student success, may suggest a need for further research on stress in polytechnic and CEGEP students. Taken together with past research on stress and self-regulation (Durand-Bush et al., 2015), our findings might point to the need for further research on stress in combination with other factors, and the potential of perseverance and self-regulation as targets of intervention. DurandBush et al. (2015) suggest that training on self-regulation skills, for example, might aid student resilience. This resilience and self-regulation capacity would allow students to be proactive in managing situational demands.

\section{Implications}

In addition to the need for further research, findings suggest some possible implications for such research among emerging adults and post-secondary students in Canada. Based on their research with early adolescents, Weber, Wagner, and Ruch (2016) suggested that researchers should focus on designing interventions for building character strengths (e.g., LaSalle, 2015; White \& Waters, 2015), and that this approach might be an important complement to current approaches which focus on addressing students' deficits. The current study suggests that an approach intended to build perseverance might also be worthy of exploration in post-secondary contexts. Past research linking perseverance to students' positive feelings about school (Weber et al., 2016) and college satisfaction (Lounsbury et al., 2009) suggests the possibility of benefits beyond school success.

\section{Conclusion}

In general, our study adds to the current literature on paths to student success in post-secondary education by examining potential predictors in two relatively understudied post-secondary settings. Our findings suggest the need to further examine maternal education in these settings and to focus on promoting student skills related to perseverance, as well as to consider the roles of identity development and cognitive development dependent on the educational context. 


\section{References}

Akgun, S., \& Ciarrochi, J. (2003). Learned resourcefulness moderates the relationship between academic stress and academic performance. Educational Psychology, 23(3), 287-294. doi:10.1080/0144341032000060129

Appleton, J. J., Christenson, S. L., Kim, D., \& Reschly, A. L. (2006). Measuring cognitive and psychological engagement: Validation of the Student Engagement Instrument. Journal of School Psychology, 44(5), 427-445. doi:10.1016/j.jsp.2006.04.002

Baldwin, C., Bensimon, E.M., Dowd, A.C., \& Kleiman, L. (2011). Measuring student success. In R. Head (Ed.), Institutional effectiveness (New Directions for Community Colleges, Vol. 153, pp. 75-88). San Francisco, CA: Jossey-Bass.

Barker, E. T., Galambos, N. L., Howard, A. L., \& Wrosch, C. (2016). Tracking affect and academic success across university: Happy students benefit from bouts of negative mood. Developmental Psychology, 52(12), 2022-2030. doi:10.1037/devo000231

Berzonsky, M. D. (2011). Identity processes. In R. J. R. Levesque (Ed.), Encyclopedia of adolescence (Vol. 1, pp. 1363-1369). New York, NY: Springer.

Berzonsky, M. D., \& Kuk, L. S. (2005). Identity style, psychosocial maturity, and academic performance. Personality and Individual Differences, 39(1), 235-247. doi:10.1016/j.paid.2005.01.010

Berzonsky, M. D., Soenens, B., Luyckx, K., Smits, I., Papini, D. R., \& Goossens, L. (2013). Development and validation of the revised Identity Style Inventory (ISI-5): Factor structure, reliability, and validity. Psychological Assessment, 25(3), 893-904.

Brown, C. S., Brown, U. J., Beale, R. L., \& Gould, J. K. (2014). Factors influencing academic success and self-esteem among diverse college students. International Journal of Education Research, 9(1), 1-14.

Childs, S. E., Finnie, R., \& Martinello, F. (2017). Postsecondary student persistence and pathways: Evidence from the YITS-A in Canada. Research in Higher Education, 58(3), 270-294. doi:10.1007/s11162-016-9424-0

Childs, S., Finnie, R., \& Mueller, R. E. (2017). Assessing the importance of cultural capital on post-secondary education attendance in Canada. Journal of Further and Higher Education. Advance online publication. doi:10.1080/0309877X.2016.1206853

Cohen, J., Cohen, P., West, S. G., \& Aiken, L. S. (2003). Applied multiple regression/ correlation analysis in the behavioral sciences (3rd ed.). Mahwah, NJ: Erlbaum.

Cohen, S., Kamarck, T., \& Mermelstein, R. (1983). A global measure of perceived stress. Journal of Health and Social Behavior, 24(4), 385-396. doi:10.2307/2136404

Dooley, M. D., Payne, A. A., \& Robb, A. L. (2012). Persistence and academic success in university. Canadian Public Policy, 38(3), 315-339. doi:10.1353/cpp.2012.0028

Duckworth, A. L., \& Yeager, D. S. (2015). Measurement matters: Assessing personal qualities other than cognitive ability for educational purposes. Educational Researcher, 44(4), 237-251. doi:10.3102/0013189X15584327 
Durand-Bush, N., McNeill, K., Harding, M., \& Dobransky, J. (2015). Investigating stress, psychological well-being, mental health functioning, and self-regulation capacity among university undergraduate students: Is this population optimally functioning? Canadian Journal of Counselling and Psychotherapy, 49(3), 253-274.

Fédération des cégeps. (2016). What is a CEGEP? Retrieved from http://www. fedecegeps.qc.ca.

Finn, J. D., \& Zimmer, K. S. (2012). Student engagement: What is it? Why does it matter? In S. L. Christenson, A. L. Reschly, \& C. Wylie (Eds.), Handbook of research on student engagement (pp. 97-131). New York, NY: Springer.

Finnie, R., Wismer, A., \& Mueller, R. E. (2015). Access and barriers to postsecondary education: Evidence from the youth in transition survey. Canadian Journal of Higher Education, 45(2), 229-262.

Fong, C. J., Davis, C. W., Kim, Y., Kim, Y. W., Marriott, L., \& Kim, S. (2017). Psychosocial factors and community college student success: A meta-analytic investigation. Review of Educational Research. Advance online publication. doi:10.3102/0034654316653479

Fredricks, J. A., \& McColskey, W. (2012). The measurement of student engagement: A comparative analysis of various methods and student self-report instruments. In S. L. Christenson, A. L. Reschly, \& C. Wylie (Eds.), Handbook of research on student engagement (pp. 763-782). New York, NY: Springer.

Frischenschlager, O., Haidinger, G., \& Mitterauer, L. (2005). Factors associated with academic success at Vienna Medical School: Prospective survey. Croatian Medical Journal, 46(1), 58-65.

Gaskin, J. (2016). Testing multi-group differences using AMOS' multigroup function. Gaskination's StatWiki. Retrieved from http://statwiki.kolobkreations.com

Grier-Reed, T., Appleton, J., Rodriguez, M., Ganuza, Z., \& Reschly, A. L. (2012). Exploring the Student Engagement Instrument and career perceptions with college students. Journal of Educational and Developmental Psychology, 2(2), 85-96. doi:10.5539/jedp.v2n2p85

Hassaskhah, J., Khanzadeh, A. A., \& Zade, S. M. (2012). The relationship between internal forms of engagement (cognitive-affective) and academic success across years of study. Issues in Language Teaching, 1(2), 251-272.

Henrich, J., Heine, S. J., \& Norenzayan, A. (2010). The weirdest people in the world? Behavioral and Brain Sciences, 33(2-3), 61-83. doi:10.1017/S0140525X0999152X

Jerrim, J., \& Vignoles, A. (2015). University access for disadvantaged children: A comparison across countries. Higher Education, 70, 903-921. doi:10.1007/s10734-0159878-6

Kline, R. (2011). Principles and practice of structural equation modeling (3rd ed.). New York, NY: The Guilford Press.

LaSalle, D. (2015). Cultivating the interaction of academics and character education: A teacher's call for modest adjustments in David Levin's Character Education Course and similar programs. Journal of Research in Character Education, 11(2), 149-158. 
Les cégeps du Québec. (2016). CEGEP is the first level of higher education in Quebec. Retrieved from http://www.cegepsquebec.ca/en/.

Lounsbury, J. W., Fisher, L. A., Levy, J. J., \& Welsh, D. P. (2009). An investigation of character strengths in relation to the academic success of college students. Individual Differences Research, 7(1), 52-69. doi:10.1016/j.lindif.2009.03.001.

Ma, X., \& Frempong, G. (2013). Profiles of Canadian postsecondary education dropouts. Alberta Journal of Educational Research, 59(2), 141-161.

McAbee, S. T., \& Oswald, F. L. (2013). The criterion-related validity of personality measures for predicting GPA: A meta-analytic validity competition. Psychological Assessment, 25(2), 532-544. doi:10.1037/a0031748

McGrath, R. E., \& Walker, D. I. (2016). Factor structure of character strengths in youth: Consistency across ages and measures. Journal of Moral Education, 45(4), 400-418. do i:10.1080/03057240.2016.1213709

Ministry of Training, Colleges and Universities. (2015). Focus on outcomes, centre on students: Perspectives on evolving Ontario's university funding model. Toronto, ON: Author. Retrieved from http://www.tcu.gov.on.ca/pepg/audiences/universities/uff/ UniversityFundingFormulaConsultationReport_2015.pdf

Newmann, F., Wehlage, G. G., \& Lamborn, S. D. (1992). The significance and sources of student engagement. In F. Newmann (Ed.), Student engagement and achievement in American secondary schools (pp. 11-39). New York, NY: Teachers College Press.

Niemiec, R. M. (2013). VIA Character Strengths: Research and practice (The first 10 years). In H. H. Knoop \& A. Delle Fave (Eds.), Well-being and cultures: Perspectives from positive psychology (pp. 11-30). New York, NY: Springer.

O’Connell, M., \& Sheikh, H. (2011). "Big Five” personality dimensions and social attainment: Evidence from beyond the campus. Personality and Individual Differences, 5O(6), 828-833. doi:10.1016/j.paid.2011.01.004

Park, N., \& Peterson, C. (2006). Moral competence and character strengths among adolescents: The development and validation of the values in action inventory of strengths for youth. Journal of Adolescence, 29(6), 891-909.

Peterson, C., \& Seligman, M. E. P. (2004). Character strengths and virtues: $A$ handbook and classification. Washington, DC: American Psychological Association.

Polytechnics Canada. (2016). What is a polytechnic? Retrieved from http://www. polytechnicscanada.ca/polytechnic-advantage/what-polytechnic

PolytechnicsCanada.(2015).Aboutus.Retrievedfromhttp://www.polytechnicscanada. ca/about-us

Poropat, A. E. (2009). A meta-analysis of the five-factor model of personality and academic performance. Psychological Bulletin, 135(2), 322-338. doi:10.1037/a0014996

Richardson, M., Abraham, C., \& Bond, R. (2012). Psychological correlates of university students' academic performance: A systematic review and meta-analysis. Psychological Bulletin, 138(2), 353-387. 
Ruch, W., Weber, M., Park, N., \& Peterson, C. (2014). Character strengths in children and adolescents: Reliability and initial validity of the German Values in Action Inventory of Strengths for Youth (German VIA-Youth). European Journal of Psychological Assessment, 30(1), 57-64. doi:10.1027/1015-5759/a000169.

Saldaña, O., Escartín, J., Torres, L., Varela-Rey, A., Martín-Peña, J., RodríguezCarballeiraa, Á.,...Vidal, T. (2014). University students' strengths associated with an optimal academic and professional performance. Procedia-Social and Behavioral Sciences, 141, 30-34.

Schafer, J. L., \& Graham, J. W. (2002). Missing data: Our view of the state of the art. Psychological Methods, 7(2), 147-177. doi:10.1037/1082-989X.7.2.147.

Seabi, J., \& Payne, J. (2013). Effects of identity processing styles on academic achievement of first year university students. International Journal of Educational Management, 27(3), 311-322. doi: 10.1108/09513541311306503

Shah, M., Hasan, S., Malik, S., \& Sreeramareddy, C. T. (2010). Perceived stress, sources and severity of stress among medical undergraduates in a Pakistani medical school. $B M C$ Medical Education, 1O(1), 1-8. doi:10.1186/1472-6920-10-2

Smits, I., Berzonsky, M. D., Soenens, B., Luyckx, K., Goossens, L., Kunnen, S., \& Bosma, H. (2008). The Identity Style Inventory 4: Internal research report. Leuven, Belgium: Catholic University Leuven.

Statistics Canada. (2016). Postsecondary enrolments by institution type, sex and program groups. Retrieved from http://www.statcan.gc.ca/tables-tableaux/sum-som/ lo1/cst01/educ74a-eng.htm

Stelnicki, A. M., Nordstokke, D. W., \& Saklofske, D. H. (2015). Who is the successful university student? An analysis of personal resources. Canadian Journal of Higher Education, 45(2), 214-228.

Strolin-Goltzmam, J., Woodhouse, V., Suter, J., \& Werrbach, M. (2016). A mixed method study on educational well-being and resilience among youth in foster care. Children and Youth Services Review, 70, 30-36. doi:10.1016/j.childyouth.2016.08.014

Struthers, C. W., Perry, R. P., \& Menec, V. H. (2000). An examination of the relationship among academic stress, coping, motivation, and performance in college. Research in Higher Education, 41(5), 581-592. doi:10.1023/A:1007094931292

Vedel, A. (2014). The Big Five and tertiary academic performance: A systematic review and meta-analysis. Personality and Individual Differences, 71(2014), 66-76. doi: 10.1016/j.paid.2014.07.011

Weber, M., Wagner, L., \& Ruch, W. (2016). Positive feelings at school: On the relationships between students' character strengths, school-related affect, and school functioning. Journal of Happiness Studies, 17(1), 341-355. doi:10.1007/s10902-0149597-1

White, M. A., \& Waters, L. E. (2015). A case study of 'The Good School:' Examples of the use of Peterson's strengths-based approach with students. Journal of Positive Psychology, 10(1), 69-76. doi:10.1080/17439760.2014.920408 


\section{Contact Information}

Heather Ramey

Bachelor of Child and Youth Care Program

Humber Institute of Technology and Advanced Learning

heather.ramey@humber.ca

Heather Ramey is a Professor in the Bachelor of Child and Youth Care Program at the Humber Institute of Technology and Advanced Learning (ITAL), and an adjunct professor in the Department of Child and Youth Studies at Brock University. She is also the CoDirector of Research at the Centre of Excellence for Youth Engagement.

Heather Lawford is an Associate Professor in the Department of Psychology at Bishop's University and an Adjunct Professor in the Department of Child and Youth Studies at Brock University. She is also the Co-Director of Research at the Centre of Excellence for Youth Engagement.

Heather Chalmers is an Associate Professor in the Department of Child and Youth Studies at Brock University. Her research interests include young carers, who are children and youth who provide care for their family member(s), and youth gambling and other risk behaviours.

Yana Lakman is a PhD student in the Department of Child and Youth Studies at Brock University. Her current research focuses on young carers' caregiving role and how it may impact attachment to their parents. 